\title{
Relationship between tolerance factor and temperature coefficient of permittivity of temperature-stable high permittivity $\mathrm{BaTiO}_{3}-\mathrm{Bi}(\mathrm{Me}) \mathrm{O}_{3}$ compounds
}

\author{
Natthaphon Raengthon ${ }^{*} \dagger, \star$, Connor McCue ${ }^{\dagger}$ and David P. Cann ${ }^{\dagger}$ \\ *Department of Materials Science, Faculty of Science \\ Chulalongkorn University, Pathumwan, Bangkok 10330, Thailand \\ and \\ $\dagger_{\text {Materials Science, School of Mechanical }}$ \\ Industrial, and Manufacturing Engineering, Oregon State University \\ Corvallis, Oregon 97331, USA \\ tNatthaphon.R@chula.ac.th
}

Received 18 November 2015; Revised 7 December 2015; Accepted 8 December 2015; Published 16 February 2016

\begin{abstract}
The temperature coefficient of permittivity $(\mathrm{TC} \varepsilon)$ of $\mathrm{BaTiO}_{3}-\mathrm{Bi}(\mathrm{Me}) \mathrm{O}_{3}$ solid solutions were investigated. It was determined that as the tolerance factor was decreased with the addition of $\mathrm{Bi}(\mathrm{Me}) \mathrm{O}_{3}$, the $\mathrm{TC} \varepsilon$ shifted from large negative values to $\mathrm{TC} \varepsilon$ values approaching zero. It is proposed that the different bonding nature of the dopant cation affects the magnitude and temperature stability of the permittivity. This study suggests that the relationship between tolerance factor and TC $\varepsilon$ can be used as a guide to design new dielectric compounds exhibiting temperature-stable high permittivity characteristics, which is similar to past research on perovskite and pyrochlore-based microwave dielectrics.
\end{abstract}

Keywords: Tolerance factor; temperature coefficient of permittivity; dielectric; temperature stable; titanate perovskite.

\section{Introduction}

The perovskite $\left(\mathrm{ABO}_{3}\right)$ structure is well known to exhibit excellent electrical properties that make it suitable for a variety of electronic applications. Most importantly, the electrical properties can be engineered via chemical modifications in order to obtain insulating, semiconducting, and conducting characteristics. ${ }^{1-5}$ In the perovskite structure, the tolerance factor $(t)$ is often used to determine the structural stability, which can be calculated from Eq. (1).

$$
t=\frac{R_{A}+R_{O}}{\sqrt{2}\left(R_{B}+R_{O}\right)},
$$

where $R_{A}, R_{B}$, and $R_{O}$ are the ionic radii of A-cation, B-cation, and oxygen ion, respectively. For ideal cubic perovskites such as $\mathrm{SrTiO}_{3}$ the tolerance factor equals 1.00. Stable perovskites with noncubic symmetry can be obtained when the tolerance factor deviates from 1.00. For example, $\mathrm{BaTiO}_{3}$ with a tolerance factor of 1.06 exhibits tetragonal symmetry and $\mathrm{CaTiO}_{3}$ with a tolerance factor of 0.97 exhibits orthorhombic symmetry. However, the perovskite structure is no longer stable when the tolerance factor greatly deviates from the ideal value $(t=1.00)$ such as for $\mathrm{MgTiO}_{3}(t=0.81)$, which is stabilized in the ilmenite structure.

The tolerance factor can also be applied to complex perovskites in which more than one cation occupies the A and/or
B sites $\left(\mathrm{A}^{\prime} \mathrm{A}^{\prime \prime}\right)\left(\mathrm{B}^{\prime} \mathrm{B}^{\prime \prime}\right) \mathrm{O}_{3}$. Complex perovskites exhibit structural changes as predicted from the tolerance factor but additional improvement in the electrical properties can be observed. ${ }^{6-8}$ For example, the substitution of $\mathrm{Zr}$ onto the Ti-site of $\mathrm{PbTiO}_{3}$ results in excellent piezoelectric properties in the widely used material $\mathrm{Pb}\left(\mathrm{Zr}_{0.52} \mathrm{Ti}_{0.48}\right) \mathrm{O}_{3}$ (PZT). ${ }^{9}$ Substitution of $\mathrm{Sr}$ onto the Ba-site in $\mathrm{BaTiO}_{3}$ results in a tunable dielectric capacitor $(\mathrm{Ba}, \mathrm{Sr}) \mathrm{TiO}_{3}(\mathrm{BST}) .{ }^{10}$ Lead-free piezoelectric ceramics with large piezoelectric coefficients can also be obtained in complex perovskites such as the $\mathrm{Ba}\left(\mathrm{Ti}_{0.8} \mathrm{Zr}_{0.2}\right) \mathrm{O}_{3}-\left(\mathrm{Ba}_{0.7} \mathrm{Ca}_{0.3}\right) \mathrm{TiO}_{3}$ system. ${ }^{11}$

Recent research has been focused on the development of high permittivity dielectrics with temperature-stable performance characteristics for capacitor applications requiring high temperatures $\left(>200^{\circ} \mathrm{C}\right)$. Complex perovskites based on $\mathrm{BaTiO}_{3}-\mathrm{Bi}(\mathrm{Me}) \mathrm{O}_{3}$ solid solutions have been found to be suitable candidates with promising electrical properties for compounds where the Me cation possesses an average charge of $3+$. An increase in the mole content of $\mathrm{Bi}(\mathrm{Me}) \mathrm{O}_{3}$ (with compounds such as $\mathrm{Bi}\left(\mathrm{Zn}_{1 / 2} \mathrm{Ti}_{1 / 2}\right) \mathrm{O}_{3}, \mathrm{Bi}\left(\mathrm{Mg}_{1 / 2} \mathrm{Ti}_{1 / 2}\right) \mathrm{O}_{3}$, $\left.\mathrm{Bi}\left(\mathrm{Ni}_{1 / 2} \mathrm{Ti}_{1 / 2}\right) \mathrm{O}_{3}, \mathrm{BiScO}_{3}\right)$ leads to an increase in the temperature stability of the permittivity at high temperatures. ${ }^{12-15}$ In particular, the $\mathrm{BaTiO}_{3}-\mathrm{Bi}\left(\mathrm{Zn}_{1 / 2} \mathrm{Ti}_{1 / 2}\right) \mathrm{O}_{3}-\mathrm{BiScO}_{3}$ solid solution exhibits a temperature-stable high permittivity with $\varepsilon_{r}$ greater than 1000 over the temperature range $100-400^{\circ} \mathrm{C}^{16,17}$

\footnotetext{
†Corresponding author.
}

This is an Open Access article published by World Scientific Publishing Company. It is distributed under the terms of the Creative Commons Attribution 4.0 (CC-BY) License. Further distribution of this work is permitted, provided the original work is properly cited. 
This family of compounds $\left(\mathrm{BaTiO}_{3}-\mathrm{Bi}(\mathrm{Me}) \mathrm{O}_{3}\right)$ exhibits weak relaxor ferroelectric behavior which governs the low-field and high-field dielectric behavior. ${ }^{15}$ The low-field (i.e., $\mathrm{E}<10 \mathrm{kV} / \mathrm{cm}$ ) dielectric response is characterized by a broad and diffuse temperature dependence of the permittivity. The high-field (i.e., $\mathrm{E}>10 \mathrm{kV} / \mathrm{cm}$ ) dielectric behavior shows a pseudo-linear dielectric response with a high permittivity and negligible saturation.

For capacitor applications, it is desirable to use dielectrics with temperature-stable permittivity characteristics, therefore the capacitor can be operated over a wide temperature range. The temperature coefficient of permittivity $(\mathrm{TC} \varepsilon)$ is a useful characteristic for determining the temperature stability of dielectric materials and can be obtained from Eq. (2).

$$
\mathrm{TC} \varepsilon=\frac{1}{\varepsilon}\left(\frac{\partial \varepsilon}{\partial T}\right) .
$$

In this work, the tolerance factor of the $\mathrm{BaTiO}_{3}-\mathrm{Bi}(\mathrm{Me}) \mathrm{O}_{3}$ system will be discussed and the low-field dielectric properties will be analyzed in terms of the temperature stability as defined by the TC $\varepsilon$. The important relationship between the tolerance factor and $\mathrm{TC} \varepsilon$ will be discussed based on data obtained from the $\mathrm{BaTiO}_{3}-\mathrm{Bi}(\mathrm{Me}) \mathrm{O}_{3}$ compounds as well as relevant phenomenological theories.

\section{Experimental Procedure}

Solid solutions based on $\mathrm{BaTiO}_{3}-\mathrm{Bi}(\mathrm{Me}) \mathrm{O}_{3}$ are the focus of this study, including the solid solutions $\mathrm{BaTiO}_{3}$ $\mathrm{Bi}-\left(\mathrm{Zn}_{1 / 2} \mathrm{Ti}_{1 / 2}\right) \mathrm{O}_{3} \quad$ (BT-BZT), $\quad \mathrm{BaTiO}_{3}-\mathrm{Bi}\left(\mathrm{Zn}_{1 / 2} \mathrm{Ti}_{1 / 2}\right) \mathrm{O}_{3}-$ $\mathrm{BiInO}_{3}$-(BT-BZT-BI), BaTiO ${ }_{3}-\mathrm{Bi}\left(\mathrm{Zn}_{1 / 2} \mathrm{Ti}_{1 / 2}\right) \mathrm{O}_{3}-\mathrm{BiScO}_{3}$ (BTBZT-BS), and $\mathrm{BaTiO}_{3}-\mathrm{Bi}\left(\mathrm{Zn}_{1 / 2} \mathrm{Ti}_{1 / 2}\right) \mathrm{O}_{3}-\mathrm{BiScO}_{3}-\mathrm{NaNbO}_{3}$ (BT-BZT-BS-NN). The specific compositions selected for this study are listed in Table 1 . All samples were prepared by using the solid state reaction technique. ${ }^{17}$ The dielectric data from previous studies were utilized for further analysis, including measurements at various frequencies from room temperature up

Table 1. Compositions and calculated tolerance factor $(t)$ of $\mathrm{BaTiO}_{3}-$ $\mathrm{Bi}(\mathrm{Me})-\mathrm{O}_{3}$ solid solutions.

\begin{tabular}{|c|c|}
\hline Composition & $t$ \\
\hline $0.80 \mathrm{BaTiO}_{3}-0.20 \mathrm{Bi}\left(\mathrm{Zn}_{1 / 2} \mathrm{Ti}_{1 / 2}\right) \mathrm{O}_{3}$ & 1.0256 \\
\hline $0.80 \mathrm{BaTiO}_{3}-0.10 \mathrm{Bi}\left(\mathrm{Zn}_{1 / 2} \mathrm{Ti}_{1 / 2}\right) \mathrm{O}_{3}-0.10 \mathrm{BiInO}_{3}$ & 1.0192 \\
\hline $0.75 \mathrm{BaTiO}_{3}-0.125 \mathrm{Bi}\left(\mathrm{Zn}_{1 / 2} \mathrm{Ti}_{1 / 2}\right) \mathrm{O}_{3}-0.125 \mathrm{BiInO}_{3}$ & 1.0116 \\
\hline $0.60 \mathrm{BaTiO}_{3}-0.20 \mathrm{Bi}\left(\mathrm{Zn}_{1 / 2} \mathrm{Ti}_{1 / 2}\right) \mathrm{O}_{3}-0.20 \mathrm{BiScO}_{3}$ & 0.9943 \\
\hline $0.55 \mathrm{BaTiO}_{3}-0.225 \mathrm{Bi}\left(\mathrm{Zn}_{1 / 2} \mathrm{Ti}_{1 / 2}\right) \mathrm{O}_{3}-0.225 \mathrm{BiScO}_{3}$ & 0.9875 \\
\hline $0.50 \mathrm{BaTiO}_{3}-0.25 \mathrm{Bi}\left(\mathrm{Zn}_{1 / 2} \mathrm{Ti}_{1 / 2}\right) \mathrm{O}_{3}-0.25 \mathrm{BiScO}_{3}$ & 0.9807 \\
\hline $0.70 \mathrm{BaTiO}_{3}-0.10 \mathrm{Bi}\left(\mathrm{Zn}_{1 / 2} \mathrm{Ti}_{1 / 2}\right) \mathrm{O}_{3}-0.10 \mathrm{BiScO}_{3}-0.10 \mathrm{NaNbO}_{3}$ & 1.0249 \\
\hline $0.60 \mathrm{BaTiO}_{3}-0.15 \mathrm{Bi}\left(\mathrm{Zn}_{1 / 2} \mathrm{Ti}_{1 / 2}\right) \mathrm{O}_{3}-0.15 \mathrm{BiScO}_{3}-0.10 \mathrm{NaNbO}_{3}$ & 1.0114 \\
\hline $0.50 \mathrm{BaTiO}_{3}-0.10 \mathrm{Bi}\left(\mathrm{Zn}_{1 / 2} \mathrm{Ti}_{1 / 2}\right) \mathrm{O}_{3}-0.10 \mathrm{BiScO}_{3}-0.30 \mathrm{NaNbO}_{3}$ & 1.0060 \\
\hline $0.50 \mathrm{BaTiO}_{3}-0.15 \mathrm{Bi}\left(\mathrm{Zn}_{1 / 2} \mathrm{Ti}_{1 / 2}\right) \mathrm{O}_{3}-0.15 \mathrm{BiScO}_{3}-0.20 \mathrm{NaNbO}_{3}$ & 1.0019 \\
\hline $0.45 \mathrm{BaTiO}_{3}-0.175 \mathrm{Bi}\left(\mathrm{Zn}_{1 / 2} \mathrm{Ti}_{1 / 2}\right) \mathrm{O}_{3}-0.175 \mathrm{BiScO}_{3}-0.20 \mathrm{NaNbO}_{3}$ & 0.9951 \\
\hline $0.40 \mathrm{BaTiO}_{3}-0.20 \mathrm{Bi}\left(\mathrm{Zn}_{1 / 2} \mathrm{Ti}_{1 / 2}\right) \mathrm{O}_{3}-0.20 \mathrm{BiScO}_{3}-0.20 \mathrm{NaNbO}_{3}$ & 0.9883 \\
\hline
\end{tabular}

to $500^{\circ} \mathrm{C} .{ }^{17-19}$ The dielectric properties of these solid solutions exhibited a broad and diffuse dielectric peak and it was shown previously that minor modification by the introduction of $\mathrm{Ba}$ vacancies could improve the dielectric properties and insulation resistance of the materials. ${ }^{18}$ Thus, all compounds selected in this study were nominally A-site nonstoichiometric with a batch composition fixed at $0.02 \mathrm{~mol}$ Ba-deficient. The presence of Asite vacancies in the complex perovskite structure will be taken into account in the tolerance factor calculation. The ionic radii required for the calculations were obtained from the data of Shannon and Prewitt. ${ }^{20}$ To determine the TC $\varepsilon$, the permittivity data was selected over an appropriate temperature range for analysis. In this study, the common temperature range that exhibited a monotonic trend in permittivity for all compositions was above the temperature at which the permittivity was maximum $\left(T_{\max }\right)$, which was over the range of $100^{\circ} \mathrm{C}$ to $400^{\circ} \mathrm{C}$. However, to avoid anomalous permittivity variations near $T_{\max }$ and at high temperatures due to conduction losses, the permittivity measured at $1 \mathrm{kHz}$ over temperature range $200-400^{\circ} \mathrm{C}$ was chosen for calculating the TC $\varepsilon$.

\section{Results and Discussion}

The tolerance factor of selected complex perovskite $\mathrm{BaTiO}_{3}-$ $\mathrm{Bi}(\mathrm{Me}) \mathrm{O}_{3}$ compounds is shown in Table 1. Due to the relatively small cation size of $\mathrm{Bi}^{3+}(1.36 \AA)$, it can be seen that $\mathrm{Bi}(\mathrm{Me}) \mathrm{O}_{3}$ end-members have low values of the tolerance factor. For example, the tolerance factor values of $\mathrm{Bi}\left(\mathrm{Zn}_{1 / 2} \mathrm{Ti}_{1 / 2}\right) \mathrm{O}_{3}, \mathrm{BiInO}_{3}$ and $\mathrm{BiScO}_{3}$ are equal to 0.9417 , 0.8871 , and 0.9098 , respectively, as compared to that of the $\mathrm{BaTiO}_{3}$ end-member $(t=1.0615)$. Thus, with a decreasing mole fraction of $\mathrm{BaTiO}_{3}$ or increasing mole fraction of $\mathrm{Bi}(\mathrm{Me}) \mathrm{O}_{3}$, the result is a decrease in the tolerance factor of the solid solution. In terms of ion size, the increase in concentration of larger B-cations $\left(\mathrm{Zn}^{2+}, \mathrm{In}^{3+}\right.$, and $\left.\mathrm{Sc}^{3+}\right)$ and the decrease in concentration of larger $\mathrm{A}$-cation $\left(\mathrm{Ba}^{2+}\right)$ result in a lowering of the tolerance factor in $\mathrm{BaTiO}_{3}-\mathrm{Bi}(\mathrm{Me}) \mathrm{O}_{3}$. It is noted that the ionic radii of $\mathrm{Ba}^{2+}$ and $\mathrm{Bi}^{3+}$ occupying the 12-fold coordinated site are $1.61 \AA$ and $1.36 \AA$, respectively, and the ionic radii of $\mathrm{Ti}^{4+}, \mathrm{Zn}^{2+}, \mathrm{In}^{3+}$, and $\mathrm{Sc}^{3+}$ occupying six-fold coordinated site are $0.605,0.740,0.800$, and $0.745 \AA$, respectively. ${ }^{20,21}$

The tolerance factor of $\mathrm{BaTiO}_{3}-\mathrm{Bi}\left(\mathrm{Zn}_{1 / 2} \mathrm{Ti}_{1 / 2}\right) \mathrm{O}_{3}, \mathrm{BaTiO}_{3}-$ $\mathrm{Bi}\left(\mathrm{Zn}_{1 / 2} \mathrm{Ti}_{1 / 2}\right) \mathrm{O}_{3}-\mathrm{BiInO}_{3}, \mathrm{BaTiO}_{3}-\mathrm{Bi}\left(\mathrm{Zn}_{1 / 2} \mathrm{Ti}_{1 / 2}\right) \mathrm{O}_{3}-\mathrm{BiScO}_{3}$, and $\mathrm{BaTiO}_{3}-\mathrm{Bi}\left(\mathrm{Zn}_{1 / 2} \mathrm{Ti}_{1 / 2}\right) \mathrm{O}_{3}-\mathrm{BiScO}_{3}-\mathrm{NaNbO}_{3}$ compounds was varied from greater than 1 to lower than 1 , which suggests a noncubic crystal structure. However, structural characterization by X-ray diffraction showed that the compounds exhibited a pseudocubic crystal structure, which could also be found in other related systems with similar tolerance factors, for example, $\mathrm{BaTiO}_{3}-\mathrm{BiScO}_{3},{ }^{15} \mathrm{BaTiO}_{3}-\mathrm{Bi}\left(\mathrm{Mg}_{1 / 2} \mathrm{Ti}_{1 / 2}\right) \mathrm{O}_{3},{ }^{13}$ and $\mathrm{BaTiO}_{3}-$ $\mathrm{Bi}\left(\mathrm{Ni}_{1 / 2} \mathrm{Ti}_{1 / 2}\right) \mathrm{O}_{3} .{ }^{14}$ In-depth structural characterizations of $\mathrm{BaTiO}_{3}-\mathrm{Bi}\left(\mathrm{Zn}_{1 / 2} \mathrm{Ti}_{1 / 2}\right) \mathrm{O}_{3}$ by using high resolution synchrotron $\mathrm{X}$-ray diffraction (HRXRD) and neutron pair distribution function (NPDF) techniques indicated that long-range structure of 
the compounds are indeed pseudocubic, however, the local structure (nanoscale) was found to be noncubic. This is likely a common occurrence in $\mathrm{BaTiO}_{3}-\mathrm{Bi}(\mathrm{Me}) \mathrm{O}_{3}$ solid solutions. It can be seen that the structure suggested from tolerance factor considerations and the structure observed by using high resolution diffraction techniques were in a good agreement in considering short-range structure.

The TC $\varepsilon$ of compounds listed in Table 1 was found to be in the range of $-2441 \mathrm{ppm} /{ }^{\circ} \mathrm{C}$ to $-182 \mathrm{ppm} /{ }^{\circ} \mathrm{C}$. ${ }^{17} \mathrm{As}$ the concentration of the $\mathrm{Bi}(\mathrm{Me}) \mathrm{O}_{3}$ component increased, the $|\mathrm{TC} \varepsilon|$ decreased reaching values close to zero indicating that compositions with high concentrations of $\mathrm{Bi}(\mathrm{Me}) \mathrm{O}_{3}$ exhibited stable dielectric properties. In this case, the composition with the optimum TC $\varepsilon$ was $0.50 \mathrm{BaTiO}_{3}-0.25 \mathrm{Bi}\left(\mathrm{Zn}_{1 / 2} \mathrm{Ti}_{1 / 2}\right) \mathrm{O}_{3}-$ $0.25 \mathrm{BiScO}_{3}$ with a value of $\mathrm{TC} \varepsilon=-182 \mathrm{ppm} /{ }^{\circ} \mathrm{C}$. It should be noted that this composition was near the solubility limit of this solid solution. Similar behavior was observed in the $\mathrm{BaTiO}_{3}-\mathrm{Bi}(\mathrm{Me}) \mathrm{O}_{3}$ system with different $\mathrm{Bi}(\mathrm{Me}) \mathrm{O}_{3}$ endmembers, ${ }^{12-16}$ however, TC $\varepsilon$ values were not reported for these systems. The variation of TC $\varepsilon$ as a function of tolerance factor of selected $\mathrm{BaTiO}_{3}-\mathrm{Bi}(\mathrm{Me}) \mathrm{O}_{3}$ compositions is shown in Fig. 1. A monotonic trend could be observed in which the TC $\varepsilon$ values $\left(-2441 \mathrm{ppm} /{ }^{\circ} \mathrm{C}\right.$ to $\left.-182 \mathrm{ppm} /{ }^{\circ} \mathrm{C}\right)$ approach zero as the tolerance factor decreased from 1.0256 to 0.9807 . The pseudoquaternary compounds of BT-BZT-BS-NaNbO 3 showed the same trend with the tolerance factor and the $\mathrm{TC} \varepsilon$, as shown in Fig. 1. It should be noted that BT-BMO labeled in Fig. 1 represents both pseudo-binary and pseudo-ternary compounds.

A dispersion of TC $\varepsilon$ values could be observed for compositions exhibiting tolerance factor greater than 1.01. By comparing the $0.8 \mathrm{BT}-0.2 \mathrm{BZT}(t=1.0256)$ and the $0.7 \mathrm{BT}$ $0.1 \mathrm{BZT}-0.1 \mathrm{BS}-0.1 \mathrm{NN}(t=1.0249)$ compositions, the differences in the TC $\varepsilon$ values could be due to the interruption of long range order of polar regions by multi-cations occupying $\mathrm{B}$-site of the latter compound as compare to the former

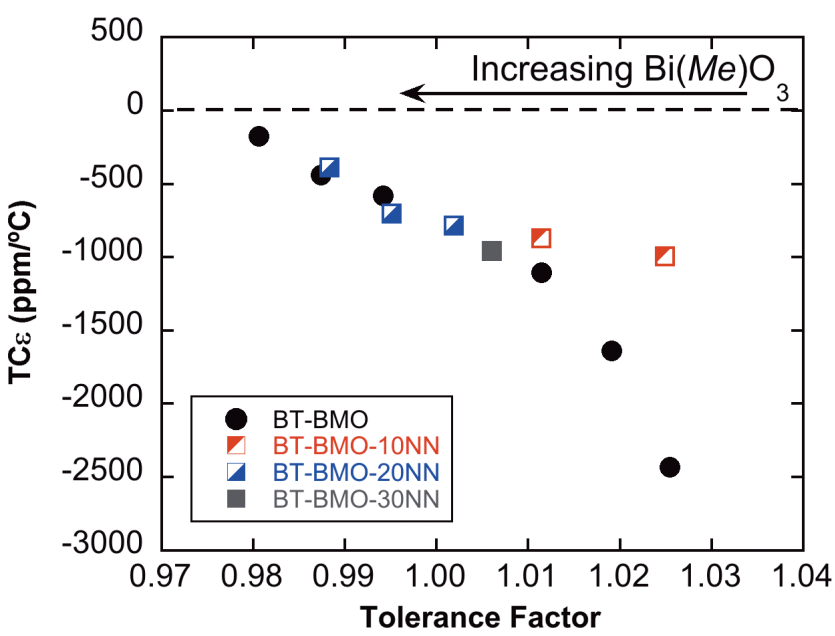

Fig. 1. TC $\varepsilon$ versus tolerance factor of selected $\mathrm{BaTiO}_{3}-\mathrm{Bi}(\mathrm{Me}) \mathrm{O}_{3}$ compounds. compound. However, the BT-BZT-BS-NN system produces dielectrics with overall lower relative permittivities compared to the other compositions presented in this investigation. Compositions with more $\mathrm{BaTiO}_{3}$ exhibited higher dielectric constants and tolerance factors but also higher temperature dependence of permittivity.

Based on the trend observed in Fig. 1, it is clear that further reduction of tolerance factor could potentially lead to an improvement in $\mathrm{TC} \varepsilon$ to obtain temperature-stable high permittivity dielectrics $(\mathrm{TC} \varepsilon \approx 0)$. However, further increasing the $\mathrm{Bi}(\mathrm{Me}) \mathrm{O}_{3}$ concentration from the $0.50 \mathrm{BaTiO}_{3}-$ $0.25 \mathrm{Bi}\left(\mathrm{Zn}_{1 / 2} \mathrm{Ti}_{1 / 2}\right) \mathrm{O}_{3}-0.25 \mathrm{BiScO}_{3}$ composition is not possible as it would exceed the solubility limit of the system, leading to the formation of secondary phases and a consequent degradation in electrical properties. Therefore, to avoid the formation of secondary phases in the system, A-cation (Ba or Bi) substitutions with an isovalent cation was considered. Specifically, the cations $\mathrm{Sr}$ and $\mathrm{Ca}$ were selected as dopant elements to substitute for the $\mathrm{Ba}$ ion in the $0.50 \mathrm{BaTiO}_{3}-0.25 \mathrm{Bi}\left(\mathrm{Zn}_{1 / 2} \mathrm{Ti}_{1 / 2}\right) \mathrm{O}_{3}-0.25 \mathrm{BiScO}_{3} \quad$ compositions. This resulted in lowering the tolerance factor from 0.9807 (undoped) to 0.9749 (Sr-doped) and 0.9714 (Ca-doped). Secondary phases were not detected by X-ray diffraction within the resolution limit of the laboratory scale instrument. Since the ionic radii of $\mathrm{Sr}^{2+}(1.44 \AA)$ and $\mathrm{Ca}^{2+}$ $(1.34 \AA)$ were smaller than that of $\mathrm{Ba}^{2+}(1.61 \AA)$, thus, it led to the reduction in the average $R_{A}-R_{O}$ distance resulting in a decrease in tolerance factor for the $\mathrm{Sr}$ and $\mathrm{Ca}$-substituted compounds.

The temperature dependence of the relative permittivity of Sr-doped and Ca-doped 0.50BaTiO $3-0.25 \mathrm{Bi}\left(\mathrm{Zn}_{1 / 2} \mathrm{Ti}_{1 / 2}\right) \mathrm{O}_{3}-$ $0.25 \mathrm{BiScO}_{3}$ compounds is shown in Fig. 2. Temperature stable behavior was maintained for both materials as the TC $\varepsilon$ values of Sr-doped and Ca-doped compositions approached zero as compared to that of the undoped composition. The substitution of Sr had only a moderate effect on improving the temperature stability, however, the $\mathrm{TC} \varepsilon$ values transitioned from $-100 \mathrm{ppm} /{ }^{\circ} \mathrm{C}$ to $+100 \mathrm{ppm} /{ }^{\circ} \mathrm{C}$ in the $\mathrm{Ca}$-doped compositions. For both cases, the permittivity decreased as the doping concentration increased. The permittivity of all Srdoped compounds remained higher than 1000. However, permittivity values of less than 1000 were obtained in the Ca-doped compounds. These results suggest that $\mathrm{Ca}$ is an effective dopant in the $0.50 \mathrm{BaTiO}_{3}-0.25 \mathrm{Bi}\left(\mathrm{Zn}_{1 / 2} \mathrm{Ti}_{1 / 2}\right) \mathrm{O}_{3}-$ $0.25 \mathrm{BiScO}_{3}$ system for achieving temperature stable dielectric properties.

These results show that decreasing the tolerance factor via the substitution of $\mathrm{Sr}$ and $\mathrm{Ca}$ ions for Ba successfully shifted the TC $\varepsilon$ closer to zero. A different rate of the change in the value of $\mathrm{TC} \varepsilon$ and the unit cell volume was observed for Sr-doped and Ca-doped compositions as shown in Fig. 3. Comparatively, at approximately the same tolerance factor for Sr-doped and Ca-doped compositions, the difference in $\mathrm{TC} \varepsilon$ value was significant $\left(\sim 60 \mathrm{ppm} /{ }^{\circ} \mathrm{C}\right)$. Following the model proposed by Levin, see Ref. 21, this difference can be 


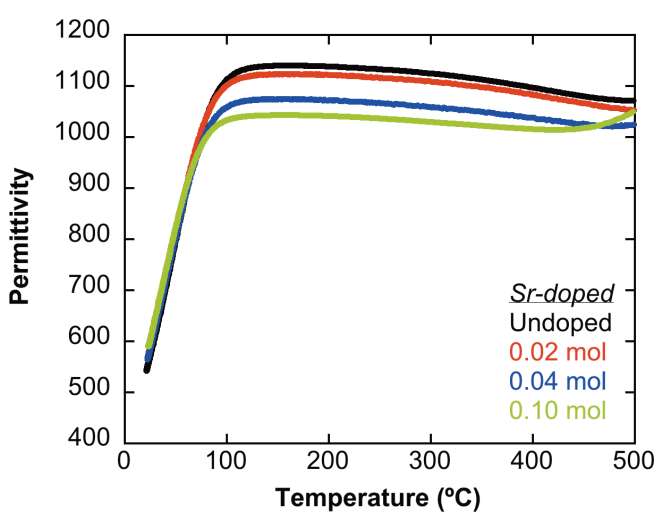

(a)

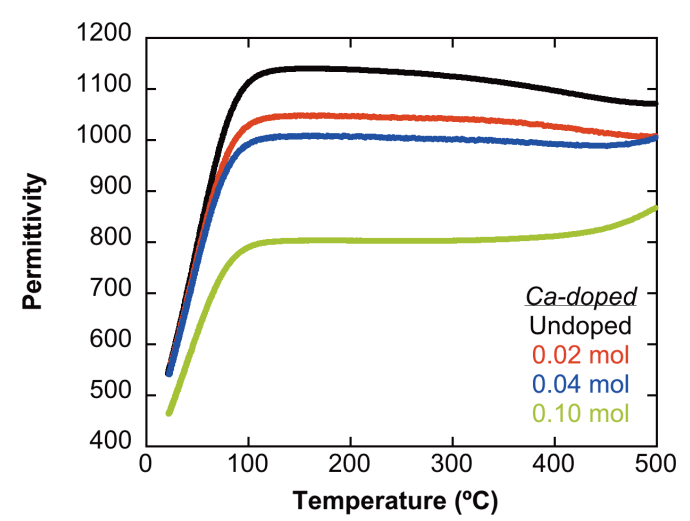

(b)

Fig. 2. Temperature dependence of permittivity of (a) Sr-doped and (b) Ca-doped $0.50 \mathrm{BaTiO}_{3}-0.25 \mathrm{Bi}_{(}\left(\mathrm{Zn}_{1 / 2} \mathrm{Ti}_{1 / 2}\right) \mathrm{O}_{3}-0.25 \mathrm{BiScO} \mathrm{O}_{3}$ compounds.

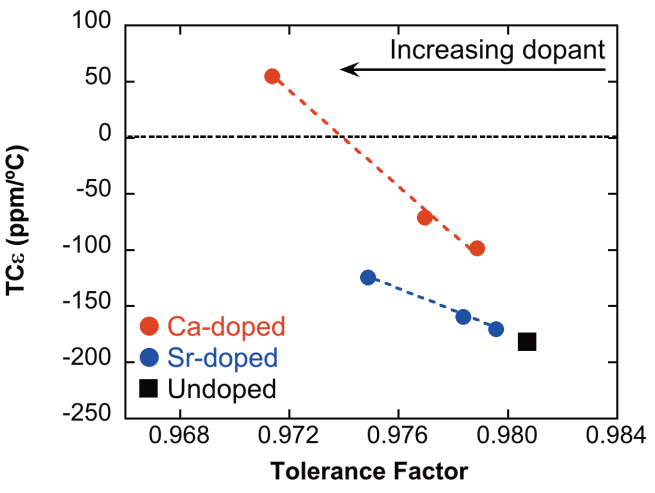

(a)

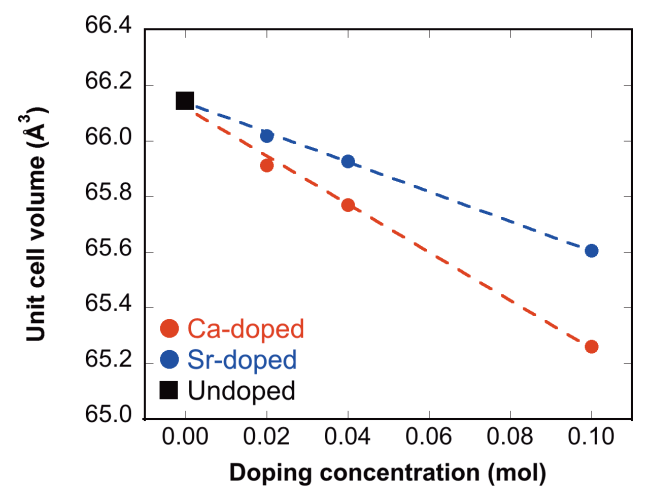

(b)

Fig. 3. (a) $\mathrm{TC} \varepsilon$ versus tolerance factor and (b) unit cell volume as a function of doping concentration for $\mathrm{Sr}$-doped and $\mathrm{Ca}-\mathrm{doped} 0.50 \mathrm{BaTiO}{ }_{3}-$ $0.25 \mathrm{Bi}\left(\mathrm{Zn}_{1 / 2} \mathrm{Ti}_{1 / 2}\right) \mathrm{O}_{3}-0.25 \mathrm{BiScO}_{3}$ compounds.

explained by the different bonding nature of the substituting ions ( $\mathrm{Sr}$ and $\mathrm{Ca}){ }^{22} \mathrm{In}$ the case of $\mathrm{Sr}$ substitution for $\mathrm{Ba}$ in $\mathrm{BaTiO}_{3}$, a reduction in unit cell volume is observed as well as a more relaxed bonding nature for $\mathrm{Sr}-\mathrm{O}$ in $\left[\mathrm{SrO}_{12}\right]$ coordination. The substitution of the $\mathrm{Ca}$ ion for $\mathrm{Ba}$ in $\mathrm{BaTiO}_{3}$ resulted in a reduced unit cell volume and an off-center position for $\mathrm{Ca}$, resulting in a strained $\mathrm{Ca}-\mathrm{O}$ bond, in $\left[\mathrm{CaO}_{12}\right]$ coordination, similar to the results obtained by Zheng. ${ }^{23}$ This strained $\mathrm{Ca}-\mathrm{O}$ bond can induce stress in the lattice, which could interrupt or clamp the polarization dynamics resulting in a reduction in permittivity and a stabilization of the permittivity over a wide temperature range. ${ }^{24}$ Based on this analysis, it is suggested that the unit cell volume reduction and the strained $\mathrm{Ca}-\mathrm{O}$ bonding characteristic played a major role in the significant reduction of permittivity. This could also mean that the presence of the strained $\mathrm{Ca}-\mathrm{O}$ bond helped further stabilize the permittivity as the temperature increased. This result supports the correlated rattling-ion model recently proposed by Krayzman et al. with the $\mathrm{BaTiO}_{3}-\mathrm{BiScO}_{3}$ solid solution. This model would suggest that the substitution of $\mathrm{Sr}$ or $\mathrm{Ca}$ for $\mathrm{Ba}$ impacts the Bi off-centering and split-site separation therefore resulting in a modification of the dielectric behavior. $^{25}$

The temperature dependence of the relative permittivity of $\mathrm{BaTiO}_{3}-\mathrm{Bi}\left(\mathrm{Zn}_{1 / 2} \mathrm{Ti}_{1 / 2}\right) \mathrm{O}_{3}-\mathrm{BiScO}_{3}-\mathrm{NaNbO}_{3}$ compounds is shown in Fig. 4. The addition of $\mathrm{NaNbO}_{3}$ was effective in shifting the temperature of the dielectric maximum $\left(T_{\max }\right)$ to temperatures as low as $-50^{\circ} \mathrm{C}$. While this shift resulted in lower room temperature dielectric loss values it was also accompanied with a lower permittivity. These results show that decreasing the tolerance factor in this system lowers the TC $\varepsilon$. Dielectric constant, dielectric loss at room temperature and $\mathrm{TC} \varepsilon$ determined from $30^{\circ} \mathrm{C}-200^{\circ} \mathrm{C}$ are shown in Table 2.

The TC $\varepsilon$ and tolerance factor relationship has been studied in detail for $(\mathrm{Ba} / \mathrm{Sr})\left(\mathrm{Me}_{1 / 3}(\mathrm{Nb} / \mathrm{Ta})_{2 / 3}\right) \mathrm{O}_{3}$ microwave dielectrics $\left(\varepsilon_{r} \approx 40\right)$ with similar results to the present work. ${ }^{26}$ Reaney et al. showed that as the tolerance factor 


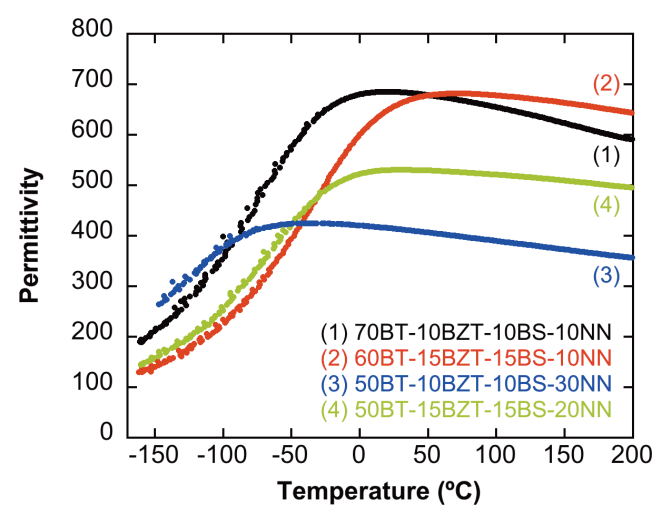

(a)

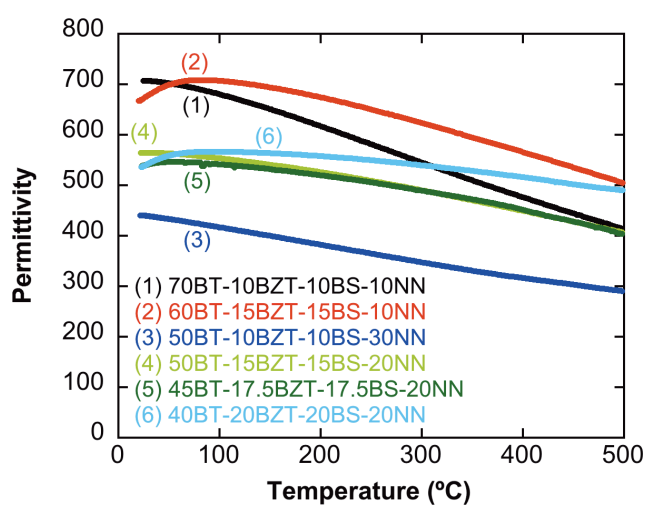

(b)

Fig. 4. Temperature dependence of permittivity of $\mathrm{BaTiO}_{3}-\mathrm{Bi}\left(\mathrm{Zn}_{1 / 2} \mathrm{Ti}_{1 / 2}\right) \mathrm{O}_{3}-\mathrm{BiScO}_{3}-\mathrm{NaNbO}_{3}$ compounds at (a) low temperatures and (b) high temperatures.

Table 2. $\mathrm{BaTiO}_{3}-\mathrm{Bi}\left(\mathrm{Zn}_{1 / 2} \mathrm{Ti}_{1 / 2}\right) \mathrm{O}_{3}-\mathrm{BiScO}_{3}-\mathrm{NaNbO}_{3}$ compounds with permittivity and dielectric loss $(\tan \delta)$ at room temperature and TC $\varepsilon$.

\begin{tabular}{lccc}
\hline Compounds & Permittivity (room temperature) & $\tan \delta$ (room temperature) & $\mathrm{TC} \varepsilon\left(\mathrm{ppm} /{ }^{\circ} \mathrm{C}\right)\left(30-200^{\circ} \mathrm{C}\right)$ \\
\hline 70BT-10BZT-10BS-10NN & 706 & 0.011 & -789 \\
60BT-15BZT-15BS-10NN & 670 & 0.052 & -476 \\
50BT-10BZT-10BS-30NN & 439 & 0.003 & -818 \\
50BT-15BZT-15BS-20NN & 563 & 0.014 & -412 \\
45BT-17.5BZT-17.5BS-20NN & 537 & 0.028 & -231 \\
40BT-20BZT-20BS-20NN & 536 & 0.048 & 159 \\
\hline
\end{tabular}

decreased $(t<0.9900)$, the TC $\varepsilon$ values transitioned from negative to positive values. Additionally, it was found that the microwave dielectric compounds with tolerance factors in the range of 0.9850 to 0.9650 exhibited the $\mathrm{TC} \varepsilon$ values close to zero, which corresponded to structures with anti-phase octahedral tilting. Compared to this study, as shown in Fig. 3(a), the compounds with $t<0.9900$ exhibited the TC $\varepsilon$ values close to zero with a negative to positive transition. This finding suggests that both groups of materials share a common relationship between the $\mathrm{TC} \varepsilon$ and the tolerance factor.

The temperature dependence of the permittivity of $(\mathrm{Ba} / \mathrm{Sr})\left(\mathrm{Me}_{1 / 3}(\mathrm{Nb} / \mathrm{Ta})_{2 / 3}\right) \mathrm{O}_{3}$ microwave dielectrics and other cubic compounds was explained by Colla et al.,${ }^{27}$ Bosman and Havinga, ${ }^{28}$ Cockbain and Harrop, ${ }^{29}$ and Harrop. ${ }^{30}$ The analysis of the macroscopic Clausius-Mossotti formula with respect to temperature showed that three physical processes contribute to the temperature dependence of permittivity in cubic compounds. First, there is an increase in macroscopic polarizability due to volume expansion. Second, there is a decrease in the number of polarizable particles per unit volume as the temperature increases because of the effect of volume expansion. Third, at constant volume, there is an intrinsic temperature dependence of the macroscopic polarizability. Based on these mechanisms, the macroscopic polarizability plays a major role in controlling the temperature dependence of the permittivity. However, due to the complicated contribution of the polarizability from multiple mechanisms in complex perovskites, ${ }^{28,29}$ a revised analysis of the Clausius-Mossotti relationship is needed in order to successfully explain the temperature dependence of permittivity of high permittivity complex perovskites such as the dielectric materials in this work.

Pyrochlore-based dielectrics are known to exhibit temperature-stable permittivity characteristics, similar to perovskite, with permittivities of approximately 200 or less. Researchers have focused on the development of Bi-based pyrochlores due to their excellent electrical properties for microwave dielectric applications. $^{31-37}$ The TC $\varepsilon$ of Bi-based pyrochlores was found to be in the range of $-1330 \mathrm{ppm} /{ }^{\circ} \mathrm{C}$ to values close to zero. Valant and Davies showed that the TC $\varepsilon$ values approached zero as the ratio of A-cation and $\mathrm{B}$-cation radii $\left(R_{A} / R_{B}\right)$ decreased in a manner such that $R_{A} / R_{B}$ was used to represent the stability of pyrochlore. ${ }^{37}$ Due to difference in structural characteristics between pyrochlore and perovskite, the tolerance factor used for perovskite cannot be directly applied to pyrochlore. Recenlty, Cai et al. re-defined the tolerance factor of pyrochlore by considering the two distinct tetrahedra $\left(\mathrm{A}_{2} \mathrm{~B}_{2}\right.$ and $\mathrm{A}_{4}$ with oxygen inside) that comprise the pyrochlore 
structure. ${ }^{38}$ Two tolerance factors were determined by Eqs. (3) and (4), as follows:

$$
\begin{gathered}
t_{1}=\frac{\sqrt{\left(x-\frac{1}{4}\right)^{2}+\frac{1}{32}}}{\sqrt{\left(x-\frac{1}{2}\right)^{2}+\frac{1}{32}}}\left(\frac{R_{A}+R_{O}}{R_{B}+R_{O}}\right), \\
t_{2}=a\left(\frac{3 \sqrt{3}}{8\left(R_{A}+R_{O}\right)}\right),
\end{gathered}
$$

where $t_{1}$ represents tolerance factor of the $\mathrm{A}_{2} \mathrm{~B}_{2}$ tetrahedra with $\mathrm{O}$ inside, $x$ represents the Wyckoff position of oxygen at $48 \mathrm{f}(x$, $1 / 8,1 / 8), t_{2}$ represents the tolerance factor of the $\mathrm{A}_{4}$ tetrahedra with $\mathrm{O}^{\prime}$ inside, and $a$ represents the lattice parameter of the pyrochlore unit cell. Previous works by Kamba et al. ${ }^{33}$ and Nino $^{39}$ suggested that dominant dielectric response of Bi-based pyrochlores originates from $\mathrm{O}^{\prime}-\mathrm{A}-\mathrm{O}^{\prime}$ bonding dynamics. Therefore, it is suggested to consider $t_{2}$ as the parameter to correlate with the dielectric response of pyrochlore structures since it is closely related to A-O $\mathrm{O}^{\prime}$ bonding. The linear relationship between $t_{2}$ and $R_{A} / R_{B}$ was determined in which $t_{2}$ decreased linearly as $R_{A} / R_{B}$ increased. ${ }^{38}$ It should be noted that the majority of pyrochlore compounds possess $t_{2}$ values in between 0.8800 to 0.9200 . However, the relationship between the TC $\varepsilon$ and the $t_{2}$ was not presented. Thus, in order to investigate this relationship, the $t_{2}$ and the $\mathrm{TC} \varepsilon$ of $(\mathrm{Bi}, \mathrm{Zn})(\mathrm{Ti}, \mathrm{Nb}) \mathrm{O}_{7}$ pyrochlores were extracted from Cai et al. ${ }^{38}$ and Valant and Davies, ${ }^{36}$ respectively, and is shown in Table 3 . It could be seen that as the $t_{2}$ increased the TC $\varepsilon$ values approached zero. Since $t_{2}$ showed a linear relationship with $R_{A} / R_{B}$ as previously mentioned, for pyrochlores the TC $\varepsilon$ approached zero when $t_{2}$ increased or $R_{A} / R_{B}$ decreased.

In general, the relationship between the tolerance factor and the $\mathrm{TC} \varepsilon$ was established for temperature-stable high permittivity $\mathrm{BaTiO}_{3}-\mathrm{Bi}(\mathrm{Me}) \mathrm{O}_{3}$ compounds, i.e., as the tolerance factor decreased, the TC $\varepsilon$ approached zero. This relationship was found to be similar to that of microwave dielectric Ba- and Sr-based perovskites. In comparison with Bi-based pyrochlore compounds, the TC $\varepsilon$ approached zero when the tolerance factor $\left(t_{2}\right)$, defined differently as compared to perovskites, increased or $R_{A} / R_{B}$ decreased. Overall, the established structure-property relationships for high permittivity perovskites, microwave dielectric perovskites, and microwave dielectric pyrochlores can be a useful guide for developing new high-permittivity materials with temperaturestable behavior.

Table 3. Bi-based pyrochlore compounds and associated tolerance factor $\left(t_{2}\right)$, and TC $\varepsilon$.

\begin{tabular}{lcc}
\hline Compounds & $t_{2}{ }^{38}$ & $\mathrm{TC} \epsilon\left(\mathrm{ppm} /{ }^{\circ} \mathrm{C}\right)^{36}$ \\
\hline$\left(\mathrm{Bi}_{1.65} \mathrm{Zn}_{0.35}\right)\left(\mathrm{Ti}_{1.65} \mathrm{Nb}_{0.35}\right) \mathrm{O}_{7}$ & 0.8970 & -1330 \\
$\left(\mathrm{Bi}_{1.50} \mathrm{Zn}_{0.50}\right)\left(\mathrm{Ti}_{1.50} \mathrm{Nb}_{0.50}\right) \mathrm{O}_{7}$ & 0.9030 & -1300 \\
$\left(\mathrm{Bi}_{1.00} \mathrm{Zn}_{1.00}\right)\left(\mathrm{Ti}_{1.00} \mathrm{Nb}_{1.00}\right) \mathrm{O}_{7}$ & 0.9260 & -870 \\
\hline
\end{tabular}

\section{Conclusions}

As the tolerance factor decreased from 1.0256 to 0.9807 due to the addition of $\mathrm{Bi}(\mathrm{Me}) \mathrm{O}_{3}$ in $\mathrm{BaTiO}_{3}-\mathrm{Bi}(\mathrm{Me}) \mathrm{O}_{3}$ compounds, the result was a shift in the temperature dependence of permittivity $(\mathrm{TC} \varepsilon$ ) to values approaching zero (from $-2441 \mathrm{ppm} /{ }^{\circ} \mathrm{C}$ to $-182 \mathrm{ppm} /{ }^{\circ} \mathrm{C}$ ). This suggests that the $\mathrm{TC} \varepsilon$ can be optimized by engineering the tolerance factor by designing the composition of perovskite solid solutions. The substitution of $\mathrm{Ba}$ in the $0.50 \mathrm{BaTiO}_{3}-0.25 \mathrm{Bi}\left(\mathrm{Zn}_{1 / 2} \mathrm{Ti}_{1 / 2}\right) \mathrm{O}_{3}-$ $0.25 \mathrm{BiScO}_{3}$ solid solution with $\mathrm{Sr}$ or $\mathrm{Ca}$ resulted in a decrease in tolerance factor, a decrease in the unit cell volume, and a decreased permittivity. However, the temperature stability of the permittivity for Sr-doped and Ca-doped was significantly improved. The bonding nature of Sr-O (relaxed) and $\mathrm{Ca}-\mathrm{O}$ (strained) played a significant role in governing the magnitude of the permittivity and the $\mathrm{TC} \varepsilon$. The range of tolerance factors that shifted $\mathrm{TC} \varepsilon$ values close to zero was found to be similar to that observed in high permittivity perovskite-based microwave dielectrics $(t \approx 0.9750-0.9800)$. This study suggests a general relationship between TC $\varepsilon$ and the tolerance factor, which can be used as a guide to design new high permittivity compounds with temperature-stable permittivity characteristics.

\section{References}

${ }^{1}$ S. Jin, T. H. Tiefel, M. Mccormack, R. A. Fastnacht, R. Ramesh and L. H. Chen, Thousandfold change in resistivity in magnetoresistive La-Ca-Mn-O films, Science 264, 413 (1994).

${ }^{2}$ N. Q. Minh, Ceramic Fuel-Cells, J. Am. Ceram. Soc. 76, 563 (1993). ${ }^{3}$ Y. Saito, H. Takao, T. Tani, T. Nonoyama, K. Takatori, T. Homma, T. Nagaya and M. Nakamura, Lead-free piezoceramics, Nature 432, 84 (2004).

${ }^{4}$ R. Waser, R. Dittmann, G. Staikov and K. Szot, Redox-based resistive switching memories - nanoionic mechanisms, prospects, and challenges, Adv. Mater. 21, 2632 (2009).

${ }^{5}$ K. D. Kreuer, Proton conductivity: Materials and applications, Chem. Mater. 8, 610 (1996).

${ }^{6}$ A. A. Bokov and Z. G. Ye, Recent progress in relaxor ferroelectrics with perovskite structure, J. Mater. Sci. 41, 31 (2006).

${ }^{7}$ B. Noheda, D. E. Cox, G. Shirane, J. Gao and Z. G. Ye, Phase diagram of the ferroelectric relaxor (1-x) $\mathrm{PbMg}_{1 / 3} \mathrm{Nb}_{2 / 3} \mathrm{O}_{3}-(\mathrm{x})$ $\mathrm{PbTiO}_{3}$, Phys. Rev. B. 66, 054104 (2002).

${ }^{8}$ C. S. Tu, I. G. Siny and V. H. Schmidt, Sequence of Dielectric anomalies and high-temperature relaxation behavior in $\mathrm{Na}_{1 / 2} \mathrm{Bi}_{1 / 2} \mathrm{TiO}_{3}$, Phys. Rev. B. 49, 11550 (1994).

${ }^{9}$ R. Guo, L. E. Cross, S. E. Park, B. Noheda, D. E. Cox and G. Shirane, Origin of the high piezoelectric response in $\mathrm{PbZr}_{1-x} \mathrm{Ti}_{x} \mathrm{O}_{3}$, Phys. Rev. Lett. 84, 5423 (2000).

${ }^{10}$ A. K. Tagantsev, V. O. Sherman, K. F. Astafiev, J. Venkatesh and N. Setter, Ferroelectric materials for microwave tunable applications, J. Electroceram. 11, 5 (2003).

${ }^{11}$ W. F. Liu and X. B. Ren, Large Piezoelectric effect in $\mathrm{Pb}$-free ceramics, Phys. Rev. Lett. 103, 257602 (2009).

${ }^{12}$ C. C. Huang and D. P. Cann, Phase transitions and dielectric properties in $\mathrm{Bi}\left(\mathrm{Zn}_{1 / 2} \mathrm{Ti}_{1 / 2}\right) \mathrm{O}_{3}-\mathrm{BaTiO}_{3}$ perovskite solid solutions, J. Appl. Phys. 104, 024117 (2008). 
${ }^{13}$ B. Xiong, H. Hao, S. J. Zhang, H. X. Liu and M. H. Cao, Structure, dielectric properties and temperature stability of $\mathrm{BaTiO}_{3}-\mathrm{Bi}\left(\mathrm{Mg}_{1 / 2} \mathrm{Ti}_{1 / 2}\right) \mathrm{O}_{3}$ perovskite solid solutions, J. Am. Ceram. Soc. 94, 3412 (2011).

${ }^{14}$ I. Fujii, K. Nakashima, N. Kumada and S. Wada, Structural, dielectric, and piezoelectric properties of $\mathrm{BaTiO}_{3}-\mathrm{Bi}\left(\mathrm{Ni}_{1 / 2} \mathrm{Ti}_{1 / 2}\right) \mathrm{O}_{3}$ ceramics, J. Ceram. Soc. Jpn. 120, 30 (2012).

${ }^{15} \mathrm{H}$. Ogihara, C. A. Randall and S. Trolier-McKinstry, Weakly coupled relaxor behavior of $\mathrm{BaTiO}_{3}-\mathrm{BiScO}_{3}$ ceramics, J. Am. Ceram. Soc. 92, 110 (2009).

${ }^{16}$ C. C. Huang, D. P. Cann, X. Tan and N. Vittayakorn, Phase transitions and ferroelectric properties in $\mathrm{BiScO}_{3}-\mathrm{Bi}\left(\mathrm{Zn}_{1 / 2} \mathrm{Ti}_{1 / 2}\right) \mathrm{O}_{3}-$ $\mathrm{BaTiO}_{3}$ solid solutions, J. Appl. Phys. 102, 044103 (2007).

${ }^{17}$ N. Raengthon, T. Sebastian, D. Cumming, I. M. Reaney and D. P. Cann, $\mathrm{BaTiO}_{3}-\mathrm{Bi}\left(\mathrm{Zn}_{1 / 2} \mathrm{Ti}_{1 / 2}\right) \mathrm{O}_{3}-\mathrm{BiScO}_{3}$ ceramics for high-temperature capacitor applications, J. Am. Ceram. Soc. 95, 3554 (2012).

${ }^{18}$ N. Raengthon and D. P. Cann, Dielectric relaxation in $\mathrm{BaTiO}_{3}-$ $\mathrm{Bi}\left(\mathrm{Zn}_{1 / 2} \mathrm{Ti}_{1 / 2}\right) \mathrm{O}_{3}$ ceramics, J. Am. Ceram. Soc. 95, 1604 (2012).

${ }^{19}$ N. Raengthon and D. P. Cann, High temperature electronic properties of $\mathrm{BaTiO}_{3}-\mathrm{Bi}\left(\mathrm{Zn}_{1 / 2} \mathrm{Ti}_{1 / 2}\right) \mathrm{O}_{3}-\mathrm{BiInO}_{3}$ for capacitor applications, J. Electroceram. 28, 165 (2012).

${ }^{20}$ R. D. Shannon and C. T. Prewitt, Effective ionic radii in oxides and fluorides, Acta. Crystallogr. B 25, 925 (1969).

${ }^{21}$ M. R. Suchomel and P. K. Davies, Predicting the position of the morphotropic phase boundary in high temperature $\mathrm{PbTiO}_{3}-$ $\mathrm{Bi}\left(\mathrm{B}^{\prime} \mathrm{B}^{\prime \prime}\right) \mathrm{O}_{3}$ based dielectric ceramics, J. Appl. Phys. 96, 4405 (2004).

${ }^{22}$ I. Levin, V. Krayzman and J. C. Woicik, Local-structure origins of the sustained Curie temperature in $(\mathrm{Ba}, \mathrm{Ca}) \mathrm{TiO}_{3}$ ferroelectrics, Appl. Phys. Lett. 102, 162906 (2013).

${ }^{23}$ R. K. Zheng, J. Wang, X. G. Tang, Y. Wang, H. L. W. Chan, C. L. Choy and X. G. Li, Effects of Ca doping on the Curie temperature, structural, dielectric, and elastic properties of $\mathrm{Ba}_{0.4} \mathrm{Sr}_{0.6-x} \mathrm{Ca}_{x} \mathrm{TiO}_{3}$ $(0<=x<=0.3)$ perovskites, J. Appl. Phys. 98, 084108 (2005).

${ }^{24} \mathrm{G}$. A. Samara, The relaxational properties of compositionally disordered $\mathrm{ABO}_{3}$ perovskites, J. Phys. Condens. Matter. 15, R367 (2003).

${ }^{25}$ V. Krayzman, I. Levin, J. C. Woicik and F. Bridges, Correlated rattling-ion origins of dielectric properties in reentrant dipole glasses $\mathrm{BaTiO}_{3}-\mathrm{BiScO}_{3}$, Appl. Phys. Lett. 107, 192903 (2015).

${ }^{26}$ I. M. Reaney, E. L. Colla and N. Setter, Dielectric and structural characteristics of Ba-based and Sr-based complex perovskites as a function of tolerance factor, Jpn. J. Appl. Phys. 33, 3984 (1994).
${ }^{27}$ E. L. Colla, I. M. Reaney and N. Setter, Effect of structuralchanges in complex perovskites on the temperature-coefficient of the relative permittivity, J. Appl. Phys. 74, 3414 (1993).

${ }^{28}$ A. J. Bosman and E. E. Havinga, Temperature dependence of dielectric constants of cubic ionic compounds, Phys. Rev. 129, 1593 (1963).

${ }^{29}$ A. G. Cockbain and P. J. Harrop, The temperature coefficient of capacitance, Br. J. Appl. Phys. 1, 1109 (1968).

${ }^{30} \mathrm{P}$. J. Harrop, Temperature coefficient of capacitance of solids, J. Mater. Sci. 4, 370 (1969).

${ }^{31}$ C. Ang, Z. Yu, H. J. Youn, C. A. Randall, A. S. Bhalla, L. E. Cross and M. Lanagan, Dielectric properties of $\mathrm{Bi}_{2} \mathrm{O}_{3}-\mathrm{ZnO}-\mathrm{Ta}_{2} \mathrm{O}_{5}$ pyrochlore and zirconolite structure ceramics, Appl. Phys. Lett. 82, 3734 (2003)

${ }^{32}$ D. P. Cann, C. A. Randall and T. R. Shrout, Investigation of the dielectric properties of bismuth pyrochlores, Solid. State. Commun. 100, 529 (1996).

${ }^{33}$ S. Kamba, V. Porokhonskyy, A. Pashkin, V. Bovtun, J. Petzelt, J. C. Nino, S. Trolier-McKinstry, M. T. Lanagan and C. A. Randall, Anomalous broad dielectric relaxation in $\mathrm{Bi}_{1.5} \mathrm{Zn}_{1.0} \mathrm{Nb}_{1.5} \mathrm{O}_{7}$ pyrochlore, Phys. Rev. B. 66, 054106 (2002).

${ }^{34}$ C. C. Khaw, K. B. Tan and C. K. Lee, High temperature dielectric properties of cubic bismuth zinc tantalate, Ceram. Int. 35, 1473 (2009).

${ }^{35}$ J. C. Nino, M. T. Lanagan and C. A. Randall, Dielectric relaxation in $\mathrm{Bi}_{2} \mathrm{O}_{3}-\mathrm{ZnO}-\mathrm{Nb}_{2} \mathrm{O}_{5}$ cubic pyrochlore, J. Appl. Phys. 89, 4512 (2001).

${ }^{36} \mathrm{M}$. Valant and P. K. Davies, Synthesis and dielectric properties of pyrochlore solid solutions in the $\mathrm{Bi}_{2} \mathrm{O}_{3}-\mathrm{ZnO}-\mathrm{Nb}_{2} \mathrm{O}_{5}-\mathrm{TiO}_{2}$ system, J. Mater. Sci. 34, 5437 (1999).

${ }^{37}$ M. Valant and P. K. Davies, Crystal chemistry and dielectric properties of chemically substituted $\left(\mathrm{Bi}_{1.5} \mathrm{Zn}_{1.0} \mathrm{Nb}_{1.5}\right) \mathrm{O}_{7}$ and $\mathrm{Bi}_{2}\left(\mathrm{Zn}_{2 / 3} \mathrm{Nb}_{4 / 3}\right) \mathrm{O}_{7}$ pyrochlores, J. Am. Ceram. Soc. 83, 147 (2000).

${ }^{38}$ L. Cai, A. L. Arias and J. C. Nino, The tolerance factors of the pyrochlore crystal structure, J. Mater. Chem. 21, 3611 (2011).

${ }^{39}$ J. C. Nino, Fundamental structure-property relationships towards engineering of an integrated NPO capacitor for bismuth pyrochlore systems, Ph.D. Thesis, The Pennsylvania State University, May 2002. 